\title{
Program Layanan Bimbingan Karir untuk Meningkatkan Kompetensi Siswa SMK
}

\section{Fitriyah Nurdianah, Mumu Muzayyian Maq}

Universitas Nadhlatul Ulama Cirebon

fitriyafadwa22@gmail.com

\section{Article History}

received 30/10/2021

\begin{abstract}
The unemployment rate for SMK graduates in Indonesia is still high, this is due to the lack of competence of graduates with industry needs. The competence in question is a supporting competency. The results obtained from the distribution of developmental task inventory (ITP) at SMK Salafiyah Cirebon, namely the average aspect of student career readiness insight is $4.46 \%$, standard deviation is 0.40 and coefficient of variance is $16.44 \%$, meaning that the need for career readiness insight is very necessary. for student. The competence in question is an insight into career readiness as part of the supporting competencies so that students are ready to face the world of work. The purpose of this study was to describe the competence of students and the feasibility of a career guidance program to improve the competence of student participants. The research method used is RnD with the ADDIE model, with five steps, namely: (1) analysis, (2) design, (3) development, (4) implementation, and (5) evaluation (evaluation). The product developed is in the form of a career guidance service program supporting competency in the aspect of career readiness insight material. The feasibility of the program involves experts in the field of guidance and counseling science, as well as product trials to a limited group. Based on the results of the assessment, the career guidance service program to improve the competence of vocational students is declared feasible to be implemented in vocational students.
\end{abstract}

Keywords: program, service, career guidance, competence

\begin{abstract}
Abstrak
Tingkat pengangguran lulusan SMK di Indonesia masih tinggi, hal tersebut disebabkan oleh kurang sesuainya kompetensi lulusan dengan kebutuhan industry. Kompetensi yang dimaksud adalah supporting competency. Hasil yang didapat dari penyebaran inventory tugas perkembangan (ITP) di SMK Salafiyah Cirebon yaitu rata-rata aspek wawasan kesiapan karir siswa $4,46 \%$, simpangan baku 0,40 dan koefisien variansi $16,44 \%$, artinya kebutuhan akan wawasan kesiapan karir sangat diperlukan bagi siswa. Kompetensi yang dimaksud adalah wawasan kesiapan karir sebagai bagian dari kompetensi penunjang agar siswa siap untuk menghadapi dunia kerja. Tujuan penelitian ini untuk menggambarkan kompetensi siswa dan kelayakan program layanan bimbingan karir untuk meningkatkan kompetensi peserta siswa. Metode penelitian yang digunakan yaitu $\mathrm{RnD}$ dengan model $\mathrm{ADDIE}$, dengan lima langkah yaitu: (1) analisis (analyze), (2) perancangan (design), (3) pengembangan (development), (4) implementasi (implementation), dan (5) evaluasi (evaluation). Produk yang diikembangkan yaitu berupa program layanan bimbingan karir supporting competency pada aspek materi wawasan kesiapan karir. Kelayakan program melibatkan ahli bidang keilmuan bimbingan dan konseling, serta uji coba produk kepada kelompok terbatas. Berdasarkan hasil penilaian, maka program layanan bimbingan karir untuk meningkatkan kompetensi siswa SMK dinyatakan layak untuk diimplementasikan pada siswa SMK.
\end{abstract}

Kata kunci: Program, Layanan, Bimbingan Karir, Kompetensi 


\section{PENDAHULUAN}

Pendidikan nasional berfungsi mengembangan kemampuan dan membentuk watak serta peradaban bangsa yang bermartabat dalam rangka mencerdaskan kehidupan bangsa, bertujuan untuk berkembangnya potensi siswa agar menjadi manusia yang beriman dan bertakwa kepada Tuhan Yang Maha Esa, berakhlak mulia, sehat, berilmu, cakap, kreatif, mandiri, dan menjadi warga negara yang demokratis serta bertanggung jawab(Habe \& Ahiruddin, 2017). Salah satu dari jenis pendidikan yaitu kejuruan, yang dikenal dengan Sekolah Menengah Kejuruan (SMK). Sekolah Menengah Kejuruan (SMK) adalah salah satu bentuk satuan pendidikan formal yang menyelenggarakan pendidikan kejuruan pada jenjang pendidikan menengah sebagai lanjutan dari SMP/MTs atau bentuk lain yang sederajat atau lanjutan dari hasil belajar yang diakui sama/setara SMP/MTs. Dimana pendidikan kejuruan merupakan pendidikan menengah yang mempersiapkan siswa terutama untuk bekerja dalam bidang tertentu. Oleh karena itu, dalam rangka persiapan menunjang pekerjaan diperlukan kompetensi.

Undang-Undang Sisdiknas juga memberikan arahan yang jelas, bahwa tujuan pendidikan harus dicapai salah satunya melalui penerapan kurikulum berbasis kompetensi. Kompetensi lulusan program pendidikan harus mencakup tiga kompetensi, yaitu sikap, pengetahuan, dan keterampilan, sehingga yang dihasilkan adalah manusia seutuhnya. Dengan demikian tujuan pendidikan nasional perlu dijabarkan menjadi himpunan kompetensi dalam tiga ranah kompetensi (sikap, pengetahuan, keterampilan). Masyarakat mengharapkan lulusan pendidikan formal Sekolah Menengah Kejuruan (SMK) memiliki kompetensi yang tinggi bersaing di pasar tenaga kerja, baik regional, nasional dan internasional. Konsekuensinya, SMK dituntut untuk menghasilkan lulusan yang siap bekerja, memiliki sikap, watak dan perilaku wirausaha, serta kecakapan hidup (life skill) untuk bekerja, sesuai dengan kebutuhan dunia usaha dan dunia industri, maupun berwirausaha. (Sutianah, 2020)

Definisi kompetensi secara umum yaitu seperangkat sikap, pengetahuan dan keterampilan yang dimiliki, dihayati, dan dikuasai oleh siswa setelah mempelajari suatu muatan pembelajaran, menamatkan suatu program, atau menyelesaikan suatu pendidikan tertentu. (Pemerintah et al., 2013). Selaras dengan pendapat Becker, Huselid, dan Ulrich mengemukakan bahwa kompetensi merupakan pengetahuan, kemampuan atau keahlian (keterampilan) yang dimiliki seseorang yang secara langsung mempengaruhi kinerjanya.(Amalia \& Suwatno, 2016). Jadi dapat diartikan yang dimaksud dengan kompetensi merupakan seperangkat sikap, pengetahuan, dan keterampilzan yang diwujudkan dalam kebiasaan berfikir serta bertindak siswa.

Terdapat tiga kelompok kompetensi yang dibutuhkan industri yaitu kompetensi dasar (base competency), kompetensi inti (core competency), kompetensi penjunjang (supporting competency). Kompetensi penunjang (supporting competency) yaitu merupakan kombinasi keterampilan, pengetahuan dan kecakapan dalam hal mental dan sikap (thinking attitude), ekspresi kualitas personal (personal quality), dan kecakapan bekerja sama dengan orang lain (working with others) sehingga seorang lulusan SMK memiliki kecakapan dalam memberikan impresi lebih pada profesinya. (Khurniawan, 2018)

Sejalan dengan pendapat Widarto, (2012, hlm 3), menyebutkan bahwa di abad 21 ini, siswa SMK dituntut memiliki delapan kompetensi lulusan, yakni: (1) communication skills, (2) critical and creative thinking, (3) information/digital literacy, (4) inquiry/reasoning skills, (5) interpersonal skills, (6) multicultural/multilingual literacy, (7) problem solving, dan (8) technological/vocational skils. Dari delapan kompetensi siswa SMK tersebut, kompetensi 1 sampai dengan 7 merupakan soft skills, sementara kompetensi 8 merupakan hard skills. (Sutianah, 2020). US-based Partnership for 21stCentury Skill (P21), mengidentifikasi kompetensi yang diperlukan di abad ke-21 
yaitu "The4Cs"- communication, collaboration, critical thinking, dan creativity.(Winaryati, 2018).

Berkaitan dengan tersebut, pada kenyataannya masih terdapat permasalahan yaitu masih tinggi nya tingkat pengangguran lulusan SMK yang disebabkan oleh kurang sesuainya kompetensi lulusan dengan kebutuhan industri.(Khurniawan, 2018) hal tersebut diperkuat dengan data Badan Pusat Statistika (BPS_Pengangguran Meningkat, Lulusan SMK Mendominasi, n.d.) Jawa Barat yang menempati peringkat pertama sebagai provinsi yang paling banyak memiliki tingkat pengangguran terbuka (TPT) secara nasional 7,73 persen.

Oleh karena itu, untuk mencapai kompetensi siswa diperlukan sebuah program bimbingan karir. Layanan atau program bimbingan karir di Indonesia seharusnya memahami dan memenuhi kebutuhan-kebutuhan siswa dalam perkembangan karir sehingga memiliki keterampilan karir pada saat meninggalkan bangku sekolah. Hoyt (2001) mengemukakan ada empat kebutuhan utama yaitu kebutuhan untuk : a. merencanakan pendidikan pasca sekolah menengah yang berorientasi karir; $b$, memperoleh keterampilan umum dalam cakap kerja, adaptasi kerja, dan peningkatan kerja sehingga mampu mengikuti perubahan dunia kerja setelah dewasa; c. penekanan pentingnya nilai-nilai kerja; d.merencanakan cara-cara menyibukkan diri dalam pekerjaan sebagai bagian dari keseluruhan perkembangan karir. (Juwitaningrum \& Indonesia, 2013)

Lembaga pendidikan formal yang ada di Indonesia tidak terlepas dari tiga pilar komponen yaitu bidang manajerial, pengajaran, dan pembinaan. Pembinaan yang dimaksud adalah fungsi dari tugas guru bimbingan konseling. Bimbingan karir adalah bagian dari layanan bimbingan konseling yang merupakan rangkaian proses pemberian pembinaan siswa khususnya bidang karir. Bimbingan dan konseling pada suatu pendidikan diselenggarakan untuk membantu siswa dalam mencapai tugastugas perkembanganya (Kemendikbud, 2016).

Bimbingan karir merupakan layanan pemenuhan kebutuhan perkembangan individu sebagai bagian integral pendidikan. Bimbingan terkait dengan perkembangan kemampuan kognitif, afektif, atau keterampilan individu dalam mewujudkan konsep diri yang positif, memahami proses pengambilan keputusan, atau perolehan pengetahuan dalam keterampilan yang akan membantu dirinya memasuki sistem kehidupan sosial budaya yang terus beubah (Supriatna \& Budiman, 2009).

Hasil studi pendahuluan yang diperoleh di SMK Salafiyah Cirebon bahwa pada dasarnya sudah terdapat layanan bimbingan karir yang difasilitasi oleh guru bimbingan konseling (BK) dan bursa kerja khusus. Akan tetapi, terdapat dua kompetensi siswa masih rendahnya pengetahuan dan kecakapan dalam hal mental dan sikap serta ekspresi kualitas personal ketika terserap oleh dunia industri. Misalnya siswa mengundurkan diri dari dunia industri karena alasan jarak antara rumah dan industri, tidak siap untuk menerima jobdescription posisi yang dituju, ketidaksiapan untuk bekerja sama dengan team kerja. Dengan demikian kondisi tersebut menjadi dasar dari penelitian ini. Untuk mengatasi permasalahan tersebut, disusunlah sebuah program layanan bimbingan karir guna mempersiapkan kompetensi siswa.

Berdasarkan latar belakang di atas, masalah penelitian difokuskan pada kelayakan program bimbingan karir untuk meningkatkan kompetensi siswa SMK. Tujuan penelitian ini adalah untuk mengetahui kelayakan program bimbingan karir untuk meningkatkan kompetensi siswa SMK.

\section{METODE}

Metode penelitian yang digunakan dalam penelitian ini yaitu riset dan pengembangan (RnD) dengan model ADDIE (Sugiyono, 2017). Langkah-langkah penelitian, yaitu: (1) Analyze, (2) Design, (3) Developmnet, (4) implementation, (5) 
evaluation. Metode $\mathrm{RnD}$ digunakan sebagai a process used to develop and validate educational product (Pujiastuti et al., 2020). Produk yang dimaksud adalah program layanan bimbingan karir yang dilaksanakan secara terstruktur dan sistematis, mulai dari assessment, penyusunan program sampai dengan evaluasi pelaksanaan.

Sumber data yang didapatkan pada penelitian ini adalah para ahli bidang keilmuan bidang bimbingan dan konseling dan siswa kelas XII.TKJ 1 SMK Salafiyah Cirebon. Data-data yang dikumpulkan melalui evaluasi yang dikelompok menjadi tiga bagian, yaitu: (1) data evaluasi tahap pertama berupa data hasil instrument ITP (inventori tugas perkembangan) guna mengetahui kebutuhan dan permasalahan siswa, (2) data evaluasi tahap kedua berupa data hasil uji validasi keterbacaan dari para ahli keilmuan bidang bimbingan dan konseling, (3) data evaluasi tahap ketiga berupa data hasil uji coba kelompok kecil.

Teknik analisis data yang digunakan pada penelitian ini digunakan dua teknis analisis data, yaitu teknik analisis deskriptif kualitatif dan analisis deskriptif kuantitatif (Pudjawan, 2015).

\section{HASIL DAN PEMBAHASAN}

Produk yang dihasilkan dalam penelitian ini adalah program layanan bimbingan karir untuk meningkatkan kompetensi siswa SMK. Penelitian ini bertujuan untuk menggambarkan kompetensi siswa dan mengetahui kelayakan program layanan bimbingan karir guna meningkatkan kompetensi siswa. Penelitian pengembangan tidak terlepas dari need assessment untuk memahami karakteristik siswa dan mengetahui materi layanan mana yang harus diutamakan dalam bimbingan karir pada jenjang SMK. Prosedur pengembangan karir ini mengacu pada POP BK SMK atau Panduan Operasional Penyelenggaraan Bimbingan dan Konseling Sekolah Menengah Kejuruan yang dikeluarkan oleh Kementerian Pendidikan dan Kebudayaan Direktorat Jenderal Guru dan Tenaga Kependidikan dengan mengikuti tata laksana dalam panduan tersebut (Kemendikbud, 2016).

Penelitian pengembangan ini mengacu pada model ADDIE, yang memiliki langkah-langkah penelitian, yaitu: (1) analisis (analyze), (2) perancangan (design), (3) pengembangan (development), (4) implementasi (implementation), dan (5) evaluasi (evaluation). Adapun paparan penjelasannya sebagai berikut:

Tahap analisis (analyze)

Tahapan analisis berkenaan dengan proses need assessment yang ada di lapangan (Gumanti, 2016). Peneliti melakukan dua kegiatan analisis yaitu studi pendahuluan dan kajian literatur. Studi pendahuluan yang dilakukan Peneliti yaitu mengumpulkan data dengan menggunakan instrumen ITP (Inventory Tugas Perkembangan) sebagai upaya untuk melakukan "need asessment", yang disebarkan pada 190 siswa SMK Salafiyah Plumbon Cirebon dari perwakilan dua kompetensi keahalian yaitu Otomatisasi Tata Kelola Perkantoran (OTKP) dan Teknik Jaringan Komputer (TKJ). Inventory tugas perkembangan dipilih sebab berkaitan dengan kompetensi siswa berdasarkan Standar Kompetensi Kemandirian Peserta Didik atau SKKPD (Kemendikbud, 2016).

Pada penyusunan program ini aspek yang dipertimbangkan adalah aspek wawasan dan kesiapan karir, dimana aspek tersebut diperoleh dari hasil analisis kelompok yang berada diperingkat ke empat dibawah rata-rata kelompok tugas perkembangannnya yaitu 4,49. Selanjutnya dari hasil distribusi frekuensi kelompok aspek wawasan dan persiapan karir didapat rata-rata siswa 4,46 dengan simpangan baku 0,40 dan koefisien variansinya adalah $16,44 \%$. Untuk lebih jelasnya bisa dilihat grafik di bawah ini 


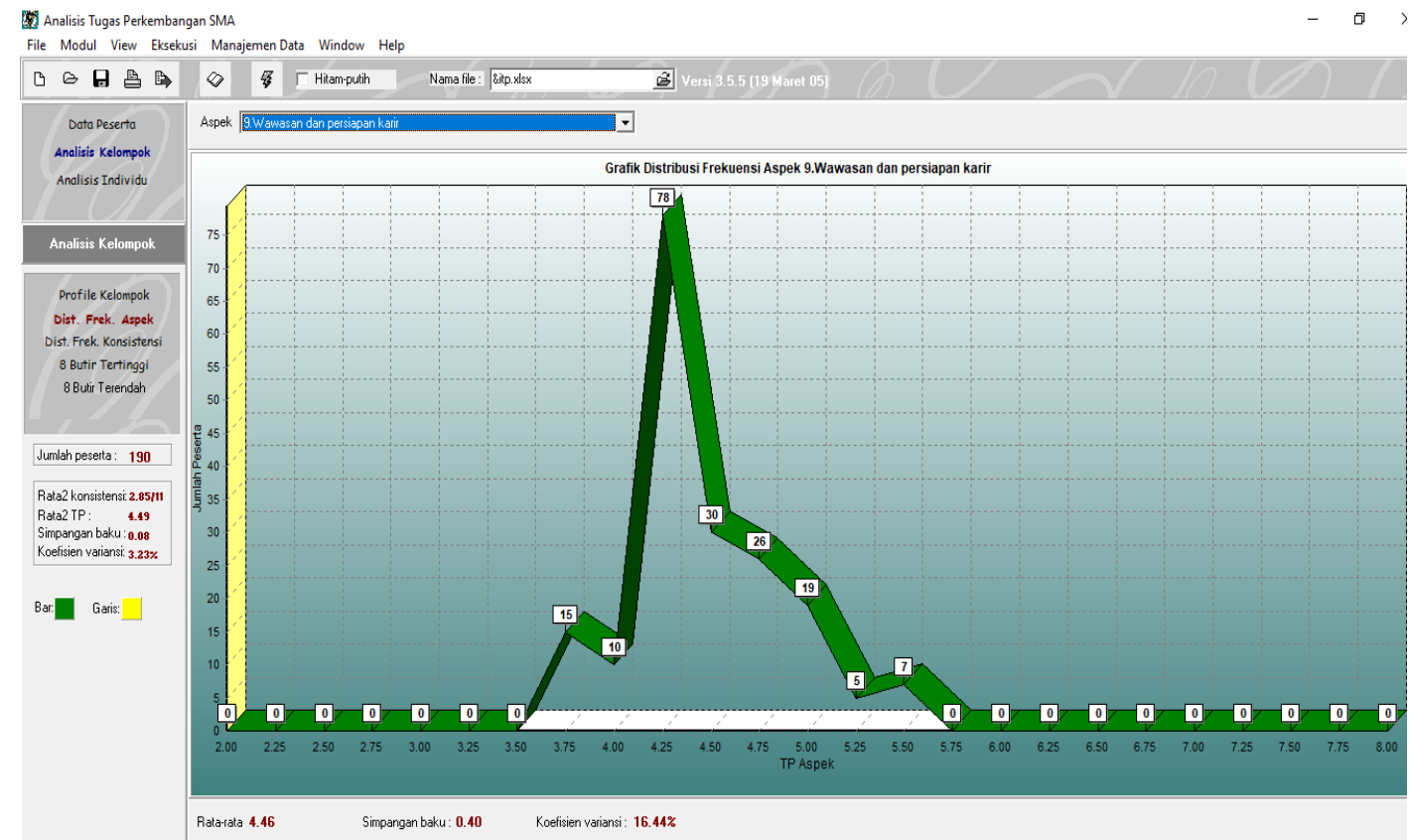

Gambar 1. Hasil Analisis Tugas Perkembangan Aspek Wawasan Kesiapan Karir Berdasarkan hasil pengolahan penyebaran instrumen ITP yang tertera pada gambar diatas, maka tahap analisis pada penelitian program layanan bimbingan karir difokuskan pada aspek SKKPD wawasan dan persiapan karir yang perlu dikembangkan guna meningkatkan kompetensi siswa. Selanjutnya kegiatan analisis kedua yaitu berupa kajian literatur dengan merumuskan tema layanan yang berkaitan dengan kompetensi wawasan dan kesiapan karir.

\begin{tabular}{|l|l|l|}
\hline Aspek SKKPD & Rumusan Kompetensi & $\begin{array}{l}\text { Pengembangan Rumusan } \\
\text { Kompetensi }\end{array}$ \\
\hline kesiapan karir dan & $\begin{array}{l}\text { Mengenal kemampuan, } \\
\text { bakat, minat, serta arah } \\
\text { kecenderungan karier dan } \\
\text { apresiasi seni }\end{array}$ & $\begin{array}{l}\text { Mengetahui jenis-jenis dan } \\
\text { karakteristik studi lanjutan } \\
\text { dan pekerjaan }\end{array}$ \\
& $\begin{array}{l}\text { Memiliki motivasi untuk } \\
\text { mempersiapkan diri } \\
\text { dengan mengembangkan } \\
\text { pengetahuan dan } \\
\text { keterampilan yang sesuai } \\
\text { dengan studi lanjutan atau } \\
\text { pekerjaan yang } \\
\text { diminatinya. }\end{array}$ \\
& $\begin{array}{l}\text { Mengidentifikasi ragam } \\
\text { alternatif studi lanjutan atau } \\
\text { pekerjaan r yang } \\
\text { mengandung relevansi } \\
\text { dengan kemampuan dan } \\
\text { minatnya. }\end{array}$ \\
\hline
\end{tabular}

Tabel 1. Rumusan Tema Layanan Berdasarkan SKKPD

Hasil analisis dari studi pendahuluan dan kaijan literatur di atas dapat digunakan sebagai data awal untuk menyusun sebuah program layanan bimbingan karir, serta mengetahui gambaran kompetensi siswa. Penyusunan program layanan bimbingan karir penelitian ini memfokuskan pada SKKPD aspek kompetensi wawasan kesiapan karir dengan materi layanan 
pengetahuan dan keterampilan supporting competency.yang sesuai dengan studi lanjutan atau pekerjaan yang diminatinya.

Tahap Perancangan (design)

Tahap ini dikenal juga dengan istilah membuat rancangan (blue print). Tahapan desain menekankan pada proses merancang produk yang sesuai dengan hasil analisis lapangan. Desain program layanan bimbingan karir berdasarkan pada hasil assessment kebutuhan siswa dan lingkungannya serta tujuan program. Adapun penyusunan rancangan program mengacu pada struktur program layanan bimbingan karir, teridi dari: 1) Rasional, 2) deskripsi kebutuhan, 3) Visi dan Misi Program, 4) Tujuan Program, 5) Sasaran Program, 6) Personel yang Terkait, 7) Rencana Operasional, 8) Pengembangan Tema, 9) Indikator Keberhasilan, 10) Evaluasi dan Followup , 11) RPL.

Penyusunan Rencana Pelaksanaan Layanan (RPL) Bimbingan dan Konseling, yang disusun sebagai acuan bagi guru bimbingan dan konseling dalam melaksanakan layanan bimbingan dan konseling. Disajikan dengan mempergunakan beragam metode, teknik dan media bimbingan serta bersifat informatif dan berorientasi membuat peserta didik mengetahui dan memahami supporting competency yang perlu dipersiapkan guna menghadapi dunia industri.

Tahap Pengembangan (development)

TProduk pada penelitian ini berupa program dengan pengembangan tema layanan bimbingan karir. Tahap pengembangan tema layanan bimbingan karir dilakukan setelah disusun program. Tugas perkembangan yaitu pada aspek wawasan kesiapan karir; dengan bidang bimbingan karir; rumusan kompetensi mampu mengenal kemampuan, bakat, minat serta arah kecenderungan karir dan apresiasi seni; materi pengembangan kompetensi pengetahuan dan keterampilan yang sesuai dengan studi lanjutan atau pekerjaan yang diminatinya; tema layanan berupa bekerja sama dengan orang lain (working with others); strategi layanan bimbingan kelompok; dan teknik bimbingan berupa diskusi kelompok

Kegiatan yang dilakukan untuk mengembangkan produk awal program layanan bimbingan karir yaitu menyusun dan menghasilkan produk layanan bimbingan karir, kemudian produk diuji validasi keterbacaan oleh ahli bidang program layanan bimbingan karir, ahli praktisi guru bimbingan dan konseling, dan ahli kebahasaan.

Penilaian ahli dilakukan untuk mengetahui apakah produk yang disusun sudah layak atau belum untuk digunakan pada penelitian. Penilaian atau uji ahli dilakukan oleh para ahli dalam perancangan model atau produk untuk mendapatkan masukan, tanggapan, kritik dan saran untuk perbaikan program yang sedang dikembangkan.

Secara keseluruhan hasil uji ahli dari pengembangan program layanan bimbingan karir dikatakan layak sudah dapat digunakan pada peserta didik SMK namun hal-hal yang perlu diperhatikan seperti dalam tujuan layanan harusnya mengacu pada Standar Kompetensi Kemandirian Peserta Didik atau SKKPD dalam hal ini karena penelitian juga meningkatkan kompetensi siswa maka diperlukan instrumen kebutuhan dan assessment yang mengacu pada aspek-aspek kompetensi siswa agar bisa dirumuskan hingga mencapai kesesuaian. Selain itu, penyusunan Rencana Pelaksanaan Layanan atau RPL yang kegrafikan perlu disesuaiakan dengan RPL inspiratif.

\begin{tabular}{|l|l|l|l|ll|}
\hline No & Komponen Program & Penilaian & Kategori & Keterangan & \\
\hline 1 & Rasional & 78 & $\begin{array}{l}\text { Sangat } \\
\text { Layak }\end{array}$ & $\begin{array}{l}\text { Tidak } \\
\text { direvisi }\end{array}$ & perlu \\
\hline
\end{tabular}




\begin{tabular}{|l|l|l|l|lc|}
\hline 2 & Deskripsi Kebutuhan & 64 & Layak & $\begin{array}{l}\text { Tidak } \\
\text { direvisi }\end{array}$ & perlu \\
\hline 3 & Visi dan Misi Program & 75 & Layak & $\begin{array}{l}\text { Tidak } \\
\text { direvisi }\end{array}$ & perlu \\
\hline 4 & Tujuan Program & 73 & Layak & $\begin{array}{l}\text { Tidak } \\
\text { direvisi }\end{array}$ & perlu \\
\hline 5 & Sasaran Program & 73 & Layak & $\begin{array}{l}\text { Tidak } \\
\text { direvisi }\end{array}$ & perlu \\
\hline 6 & Personel yang Terkait & 75 & Layak & $\begin{array}{l}\text { Tidak } \\
\text { direvisi }\end{array}$ & perlu \\
\hline 7 & Rencana Operasional & 70 & Layak & $\begin{array}{l}\text { Tidak } \\
\text { direvisi }\end{array}$ & perlu \\
\hline 8 & Pengembangan Tema & 60 & Layak & $\begin{array}{l}\text { Tidak } \\
\text { direvisi }\end{array}$ & perlu \\
\hline 9 & Indikator Keberhasilan & 72 & Layak & $\begin{array}{l}\text { Tidak } \\
\text { direvisi }\end{array}$ & perlu \\
\hline 10 & Evaluasi dan Follow up & 67 & Layak & $\begin{array}{l}\text { Tidak } \\
\text { direvisi }\end{array}$ & perlu \\
\hline 11 & RPL & 50 & Cukup Layak & Direvisi & \\
\hline
\end{tabular}

Tabel 1. Hasil Penilaian Validasi Ahli Untuk Program Layanan Bimbingan Karir

Berdasarkan pada hasil penilaian validasi ahli aspek pengembangan yang perlu direvisi yaitu pada komponen RPL. Hasil penyusunan RPL semula yaitu pada beberapa lembar halaman, selanjutnya direvisi dengan RPL inspiratif yang merujuk pada surat edaran Menteri Pendidikan dan Kebudayaan Nomor 14 Tahun 2019 tentang penyederhanaan rencana pelaksanaan pembelajaran. Surat edaran tersebut menekankan bahwa RPP saat ini (RPP inspiratif) diharapkan mencakup komponen utama: tujuan, aktivitas, dan penilaian pembelajaran. Begitu pula diterapkan pada RPL (Model Inspiratif Layanan Bimbingan Dan Konseling Sekolah Menengah Kejuruan ( Smk ), n.d.).

Tahap Implementasi (implementation)

Tahap implementasi dari penelitian ini yaitu pelaksanaan layanan bimbingan karir pengembangan tema yang sudah direvisi berdasarkan saran dan masukan dari ahli keilmuan bidang bimbingan dan konseling. Pelaksanaan diujicobakan pada kelompok yang terbatas, dengan tujuan untuk mengetahui kelayakan layanan bimbingan karir guna meningkatkan kompetensi siswa. Ujicoba layanan bimbingan karir diberikan beberapa kali pertemuan sesuai dengan rencana pelaksanaan layanan yang telah disusun.

Pengujian dilakukan dengan cara eksperimen yaitu membandingkan keadaan sebelum dan sesudah diberikan layanan. Eksperimen dilakukan dengan membandingkan hasil observasi $\mathrm{O}_{1}$ dan $\mathrm{O}_{2}$ adalah nilai perhitungan ITP aspek wawasan dan kesiapan karir. Adapun hasil perhitungan ITP sebelum dan sesudah pada kelas XII.TKJ 1 dengan jumlah siswa 19 orang sebagai berikut.

\begin{tabular}{|l|l|l|}
\hline & Sebelum & Setelah \\
\hline Rata-rata & 4,42 & 4,68 \\
\hline Simpangan baku & 0,32 & 0,41 \\
\hline Koefisien variansi & $13,06 \%$ & $15,33 \%$ \\
\hline
\end{tabular}

Tabel 2. Hasil Perhitungan ITP Aspek Wawasan dan Kesiapan Karir 
Berdasarkan tabel 2 tersebut terlihat bahwa hasil ITP pada uji coba kelompok terbatas sebelum dan setelah diberikan layanan memiliki peningkatan kompetensi wawasan dan kesiapan karir.

Tahap Evaluasi (evaluation)

Kegiatan terakhir yaitu evaluasi dari tahap implementasi pada kelas uji coba kelompok kecil. Evaluasi dilakukan pada aspek proses dan hasil layanan bimbingan karir. Teknik evaluasi menggunakan lembar evaluasi yang diisi oleh kelompok uji coba kelompok kecil. Hasil evaluasi proses secara pengembangan materi layanan kompetensi kesiapan karir siswa dirasakan menjadi kebutuhan siswa guna persiapan lulus dari smk sehingga mereka dapat diterima dunia kerja. Namun, dalam metode penyampaian layanan perlu adanya inovasi dan uji coba perlu adanya penambahan kelompok besar.

Analisis data penelitian tidak hanya sebatas pada data kuantitatif, akan tetapi juga data kualitatif, yang diperoleh dari hasil wawancara kepada kepala sekolah, wakil kepala sekolah bidang kurikulum, wakil kepala sekolah bidang hubungan industry, ketua program studi jurusan, dan guru bimbingan konseling. Berdasarkan hasil wawancara diperoleh bahwa kompetensi yang dibutuhkan siswa guna persiapan menghadapi dunia kerja tidak hanya kompetensi teknis, namun kompetensi soft skill. Kompetensi soft skill dapat diberikan oleh guru bimbingan dan konseling melalui layanan bimbingan karir. Pada dasarnya bimbingan konseling merupakan bagian integral dari pendidikan di SMK sehingga dapat berkontribusi dalam meningkatkan kompetensi dan permasalahan karir siswa. Salah satunya oleh sekolah melalui layanan bimbingan dan konseling karir. Dalam lampiran Permendikbud Nomor 111 Tahun 2014, dijelaskan bahwa ruang lingkup bimbingan karir terdiri atas pengembangan sikap positif terhadap pekerjaan, pengembangan keterampilan menempuh masa transisi secara positif dari masa sekolah ke masa bekerja, pengembangan kesadaran terhadap berbagai pilihan karir, informasi pekerjaan, ketentuan sekolah dan pelatihan kerja, kesadaran akan hubungan beragam tujuan hiduo dengan nilai , bakat, minat, kecakapan, dan kepribadian masing-masing (Putranti, 2018).

Program layanan bimbingan karir disusun berdasarkan assessment kebutuhan yang dilakukan untuk mengetahui bidang mana yang harus diprioritaskan dalam bimbingan konseling pada jenjang SMK. Assessment kebutuhan yang dilakukan sebagai tahap analisis pada metode ADDIE, yang selanjutnya data pada tahap ini dijadikan jawaban dari pertanyaan penelitian pertama, bagaimana gambaran kompetensi siswa. Instrument yang digunakan guna menggambarkan kompetensi yaitu inventory tugas perkembangan (ITP), dimana data yang ada di ITP dianalisis melalui ATP (analisis tugas perkembangan) sebagai perangkat lunak yang dirancang untuk mengolah data secara "computerized". Aspek perkembangan yang diprioritaskan adalah wawasan kesiapan karir, karena menempati urutan ke empat dari sembilan aspek perkembangan. Pengembangan standar kompetensi siswa di Indonesia tidak akan sama dengan Negara lain. Untuk standar kompetensi siswa di Indonesia disesuaikan dengan tujuan pendidikan nasional dan budaya Indonesia. Tugas perkembangan peserta didik yang telah teridentifikasi sebelumnya perlu dikembangkan lebih lanjt dalam bentuk standar kompetensi tersebut dikenal dengan istilah standar kompetensi kemandirian peserta didik (SKKPD).

Selain materi-materi ketermpilan yang dituangkan dalam inventory tugas perkembangan, peserta didik juga perlu memperbaiki soft skill sebagai supporting competency yang fungsinya sangat vital dalam menentukan 
Supporting competency atau kompetensi penunjang merupakan bagian kompetensi yang diperlukan bagi siswa SMK selain kompetensi dasar dan kompetensi inti. Yang dimaksud dengan supporting competency yaitu merupakan kombinasi keterampilan, pengetahuan dan kecakapan dalam hal mental dan sikap (thinking attitude), ekspresi kualitas personal (personal quality) dan kecakapan bekerja sama dengan orang lain (working with others) sehingga seorang lulusan SMK memiliki kecakapan dalam memberikan impresi lebih pada profesinya (Khurniawan, 2018). Dari definisi supporting competency dapat ditarik kesimpulan terdapat tiga aspek yaitu 1) mental dan sikap; 2) ekspresi kualitas personal; dan 3) kecakapan bekerja sama dengan orang lain.

\section{SIMPULAN}

Penelitian ini memiliki tujuan untuk mendeskripiskan kompetensi siswa dan kelayakan program layanan bimbingan karir untuk meningkatkan kompetensi siswa dikembangkan berdasarkan dari need assessment yang menggambarkan profil kompetensi wawasan dan persiapan karir siswa yang selama ini masih di bawah ratarata tugas perkembangan. Berdasarkan gambaran kompetensi siswa yang ada, maka disusunlah sebuah program layanan bimbingan karir. Program layanan bimbingan karir dikembangkan atas dasar tema layanan supporting competency. Selanjutnya program tersebut dinilai kelayakannya dengan uji coba terbatas pada kelompok kecil. Berdasarkan penilaian tersebut dapat disimpulkan bahwa program layanan bimbingan karir layak digunakan untuk meningkatkan kompetensi siswa.

\section{DAFTAR PUSTAKA}

Amalia, L., \& Suwatno, S. (2016). Peningkatan Kompetensi Siswa Melalui Efektivitas Competency Based Training. Jurnal Pendidikan Manajemen Perkantoran, 1(1), 30. https://doi.org/10.17509/jpm.v1i1.3267

BPS_Pengangguran Meningkat, Lulusan SMK Mendominasi. (n.d.).

Gumanti, dkk. (2016). Metodologi Penelitian Pendidikan. Mitra Wacana Media.

Habe, H., \& Ahiruddin, A. (2017). Sistem Pendidikan Nasional. EKOMBIS SAINS: Jurnal Ekonomi, Keuangan Dan Bisnis, 2(1), 39-45. https://doi.org/10.24967/ekombis.v2i1.48

Juwitaningrum, I., \& Indonesia, U. P. (2013). Program Bimbingan Karir untuk Meningkatkan Kematangan Karir Siswa SMK Career Counseling Program to Improve Career Maturity Students of SMK. 2(2), 132-147.

Kemendikbud. (2016). Panduan Operasional Penyelenggaraan Bimbingan dan Konseling Sekolah Menengah Kejuruan (SMK). Kemendikbud.

Khurniawan, D. (2018). Optimalisasi Kompetensi Lulusan SMK Dalam Industri / Teknologi Terapan.

Model Inspiratif Layanan Bimbingan Dan Konseling Sekolah Menengah Kejuruan ( Smk ). (n.d.).

Pemerintah, P., Indonesia, R., Atas, P., Rahmat, D., Yang, T., Esa, M., \& Indonesia, P. R. (2013). PP RI 322013 tentang standar nasional pendidikan.

Pudjawan, K. (2015). PENGEMBANGAN BUKU AJAR MODEL PENELITIAN Analyze Implement Evaluate Design Develop. 208-216.

Pujiastuti, E. S., Fitri, S., \& Hidayat, D. R. (2020). Pengembangan Program Bimbingan Dan Konseling Karir Sekolah Menengah Kejuruan Model Employability Skill. INSIGHT: Jurnal Bimbingan Konseling, 9(1), 8-17. https://doi.org/10.21009/insight.091.02

Putranti, D. 2018. (2018). Layanan Bimbingan Karir Di Sekolah Menengah Kejuruan Berbasis Teaching Factory. Konseling Komprehensif, Volume 5, Nomor 2, 42-47.

Sugiyono. (2017). Metode Penelitian Administrasi (Pendekatan Kuantitatif, Kualitatif, dan RnD). Penerbit Alpha Betha. 
Supriatna, M., \& Budiman, N. (2009). Bimbingan Karir di SMK. Dalam E-Book, 1-72.

Sutianah, C. (2020). Pengembangan Karakter Kebangsaan dan Karakter Wirausaha Melalui Implementasi Model Pembelajaran Teaching Factory 6 Langkah (TF-6M) (Q. Media (Ed.); Pertama). CV.Penerbit Qiara Media. https://books.google.co.id/books?id=AzzNDwAAQBAJ\&lpg=PR1\&hl=id\&pg=PR3 $\# \mathrm{v}=$ onepage \&q\&f=false

Winaryati, E. (2018). Penilaian Kompetensi Siswa Abad 21. Prosiding Seminar Nasional \& Internasional, 6(1), 6-19. 